Article

\title{
Bioactive Dimeric Abietanoid Peroxides from the Bark of Cryptomeria japonica
}

\author{
Chi-I Chang ${ }^{1,2}$, Cheng-Chi Chen ${ }^{3,+}{ }^{+}$Chiy-Rong Chen ${ }^{4}$, Ming-Der Wu ${ }^{5}$, Ming-Jen Cheng ${ }^{5}$, \\ Ping-Jyun Sung $6,7,+(1)$ and Yueh-Hsiung Kuo ${ }^{8,9,10, * \mathbb{C}}$
}

1 Department of Biological Science and Technology, National Pingtung University of Science and Technology, Pingtung 912, Taiwan; changchii@mail.npust.edu.tw

2 Research Center for Active Natural Products Development, National Pingtung University of Science and Technology, Pingtung 912, Taiwan

3 Department of Chemistry, National Taiwan University, Taipei 106, Taiwan; r93223083@ntu.edu.tw

4 Department of Life Science, National Taitung University, Taitung 950, Taiwan; gina77@nttu.edu.tw

5 Bioresource Collection and Research Center (BCRC), Food Industry Research and Development Institute (FIRDI), Hsinchu 300, Taiwan; wmd@firdi.org.tw (M.-D.W.); cmj@firdi.org.tw (M.-J.C.)

6 National Museum of Marine Biology and Aquarium, Pingtung 944, Taiwan; pjsung@nmmba.gov.tw

7 Graduate Institute of Marine Biology, National Dong Hwa University, Pingtung 944, Taiwan

8 Department of Chinese Pharmaceutical Sciences and Chinese Medicine Resources, College of Pharmacy, China Medical University, Taichung 404, Taiwan

9 Department of Biotechnology, Asia University, Taichung 413, Taiwan

10 Chinese Medicine Research Center, China Medical University, Taichung 404, Taiwan

* Correspondence: kuoyh@mail.cmu.edu.tw; Tel.: +886-4-2205-3366 (ext. 5701); Fax: +886-4-2207-1693

+ These two authors contributed equally to this paper.

Received: 10 May 2019; Accepted: 8 June 2019; Published: 10 June 2019

\begin{abstract}
Three new dimeric abietane-type diterpenoids, abieta-6,8,11,13-tetraen-12-yl 12hydroxyabieta-8,11,13-trien-7 $\alpha$-yl peroxide (1), abieta-6,8,11,13-tetraen-12-yl 12-hydroxyabieta8,11,13-trien-7 $\beta$-yl peroxide (2), and 12-hydroxyabieta-8,11,13-trien-7 $\beta$-yl 7-oxoabieta-5,8,11,13-tetraen12-yl peroxide (3), together with four known abietane-type diterpenoids (4-7) were isolated from the methanol extract of the bark of Cryptomeria japonica. Their structures were elucidated on the basis of spectroscopic analysis and comparison of NMR data with those of known analogues. At a concentration of $50 \mu \mathrm{M}$, compounds 1, 2, and 3 showed $26.2 \%, 23.6 \%$, and $35.7 \%$ inhibition towards xanthine oxidase enzyme, respectively. In addition, compound 3 also showed $24.9 \%$ inhibition toward angiotensin-converting enzyme (ACE).
\end{abstract}

Keywords: Cupressaceae; Cryptomeria japonica; dimeric abietane; diterpenoid

\section{Introduction}

The Japanese cedar, Cryptomeria japonica D. Don (Cupressaceae), belongs to the monotypic genus in the Cupressaceae [1]. It is a massive evergreen coniferous tree, growing up to $50 \mathrm{~m}$ in height. Due to the aromatic, reddish-pink in color, soft, lightweight but strong, and waterproof properties of its wood, it is planted in large quantities and used as building materials and wood products. This plant has been cultivated as an important coniferous tree species in Taiwan since 1906. Phytochemical investigations indicated the presence of monoterpenoids, sesquiterpenoids, and diterpenoids [2-24] in the leaves, heartwood, and barks of $C$. japonica. The crude extracts and secondary metabolites from this species exhibited a wide array of bioactivities including cytotoxic [23], antifungal [24], antibacterial [23], antioxidant [25], anti-inflammatory [26], and insect antifeedant [27] and repellent [18] properties. While searching for bioactive chemical ingredients of the bark of $C$. japonica, we have already reported the 
isolation of three sesquarterpenoids [28,29] and ten abietane-type diterpenoids [30-32]. Herein, the isolation and structure elucidation of three new dimeric abietane-type diterpenoids are described as well as their inhibitory activity towards xanthine oxidase and angiotensin-converting enzymes.

\section{Results and Discussion}

\subsection{Isolation and Structural Elucidation}

The $\mathrm{MeOH}$ extract of the bark of $C$. japonica was suspended in $\mathrm{H}_{2} \mathrm{O}$ and then partitioned with EtOAc and $n-\mathrm{BuOH}$, successively. The EtOAc-soluble portion was submitted to repeated silica gel column chromatography and semipreparative normal phase-HPLC to afford compounds 1-7 (Figure 1).
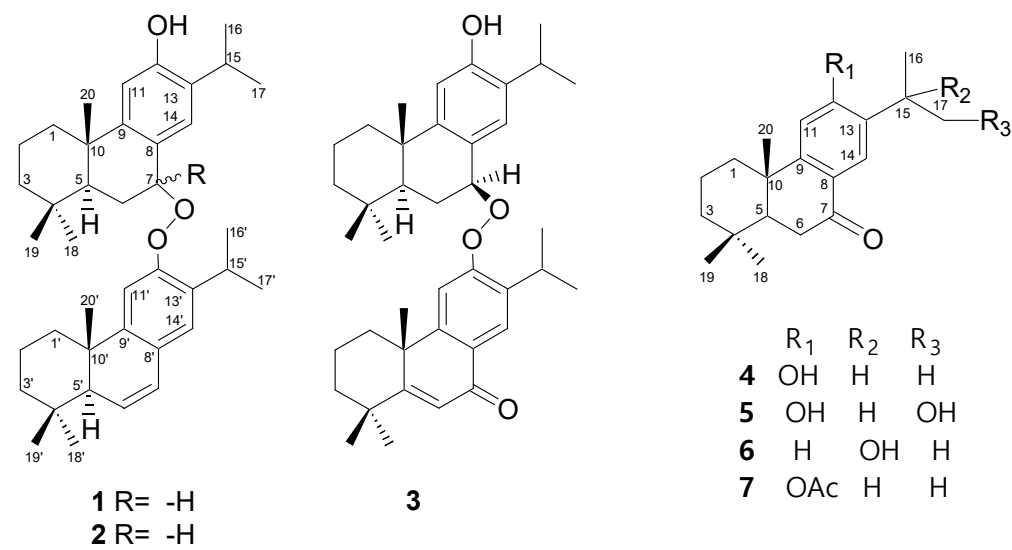

Figure 1. The chemical structures of compounds 1-7 isolated from C. japonica.

The high resolution electron impact mass spectrum (HR-EI-MS) of 1 gave a molecular ion at $\mathrm{m} / \mathrm{z}$ 584.4238 , corresponding to the molecular formula of $\mathrm{C}_{40} \mathrm{H}_{56} \mathrm{O}_{3}$, with thirteen degrees of unsaturation. The electron impact mass spectrum (EI-MS) of $\mathbf{1}$ displayed the fragmental ions at $m / z 300\left[\mathrm{C}_{20} \mathrm{H}_{28} \mathrm{O}_{2}\right]^{+}$ and $284\left[\mathrm{C}_{20} \mathrm{H}_{28} \mathrm{O}\right]^{+}$(Figure 2) and forty carbon signals were observed in the ${ }^{13} \mathrm{C}-\mathrm{NMR}$ spectrum, indicating that 1 was a dimeric diterpenoid (Figure 2). The UV and IR spectra showed absorption bands for hydroxyl $\left(3409 \mathrm{~cm}^{-1}\right)$ and aromatic $\left(\lambda_{\max } 220\right.$ and $279 \mathrm{~nm} ; 3049,1593$, and $\left.1487 \mathrm{~cm}^{-1}\right)$ groups. The ${ }^{1} \mathrm{H}$ - and ${ }^{13} \mathrm{C}-\mathrm{NMR}$ data of $\mathbf{1}$ (Table 1 ) showed one set of dehydroabietane diterpene signals for constituent upper monomer- 1 including three tertiary methyl groups $\left(\delta_{\mathrm{H}} 0.97,0.98\right.$, and 1.36 (each $3 \mathrm{H}, \mathrm{s}, \mathrm{Me}-18, \mathrm{Me}-19$, and Me-20)), an isopropyl group attached to a phenyl group $\left(\delta_{\mathrm{H}} 0.78(3 \mathrm{H}, \mathrm{d}\right.$, $J=7.0 \mathrm{~Hz}, \mathrm{Me}-16), 1.01(3 \mathrm{H}, \mathrm{d}, J=7.0 \mathrm{~Hz}, \mathrm{Me}-17)$, and $2.85(1 \mathrm{H}$, sept, $J=7.0 \mathrm{~Hz}, \mathrm{H}-15))$, two para aromatic protons $\left(\delta_{\mathrm{H}} 6.34(1 \mathrm{H}, \mathrm{s}, \mathrm{H}-14)\right.$ and $\left.6.69(1 \mathrm{H}, \mathrm{s}, \mathrm{H}-11)\right)$, a phenolic hydroxyl proton $\left(\delta_{\mathrm{H}} 4.33(1 \mathrm{H}\right.$, $\mathrm{s}$, exchangeable with $\left.\mathrm{D}_{2} \mathrm{O}\right)$ ), and a typical downshifted $\mathrm{H}_{\beta}-1$ signal of a dehydroabietane diterpene $\left(\delta_{\mathrm{H}} 1.96(1 \mathrm{H}, \mathrm{br} \mathrm{d}, J=12.0 \mathrm{~Hz})\right)$ [33]. A downshifted benzyl proton connected with a peroxyl group $\left(\delta_{\mathrm{H}} 5.86(1 \mathrm{H}, \mathrm{br} \mathrm{s}, \mathrm{H}-7)\right)$, instead of a hydroxyl group $[19,33,34]$, was assigned as $\mathrm{H}-7$, suggested by the ${ }^{1} \mathrm{H}-{ }^{1} \mathrm{H}$ COSY correlations with the two methylene protons of $\mathrm{H}-6\left(\delta_{\mathrm{H}} 2.28(1 \mathrm{H}, \mathrm{m}), \delta_{\mathrm{H}} 2.32(1 \mathrm{H}, \mathrm{m})\right)$, and HMBC correlations with $C-5\left(\delta_{C} 43.5\right)$ and C-8 $\left(\delta_{C} 145.6\right.$; Figure 3$)$. In addition, the ${ }^{1} \mathrm{H}-\mathrm{NMR}$ signal of H-7 was a broad singlet peak and showed the NOESY correlation with both $\mathrm{H}_{\alpha}-6\left(\delta_{\mathrm{H}} 2.32\right)$ and $\mathrm{H}_{\beta}-6\left(\delta_{\mathrm{H}} 2.28\right)$, hinted that the peroxyl group was attached on C-7 in $\alpha$-axial orientation [33] (Figure 3). These data proved that the structure of constituent monomer- 1 was related to $7 \alpha$-peroxyferruginol. The ${ }^{1} \mathrm{H}$ - and ${ }^{13} \mathrm{C}$-NMR data of $\mathbf{1}$ (Table 1) also exhibited another set of dehydroabietane diterpene signals for constituent lower monomer- 2 including three tertiary methyl groups $\left(\delta_{\mathrm{H}} 0.94,1.04\right.$, and 1.11 (each $3 \mathrm{H}, \mathrm{s}, \mathrm{Me}-18^{\prime}, \mathrm{Me}-19^{\prime}$, and Me-20')), an isopropyl group attached to a phenyl group $\left(\delta_{\mathrm{H}} 0.81\right.$ $\left(3 \mathrm{H}, \mathrm{d}, J=7.0 \mathrm{~Hz}, \mathrm{Me}-16^{\prime}\right), 0.98\left(3 \mathrm{H}, \mathrm{d}, J=7.0 \mathrm{~Hz}, \mathrm{Me}-17^{\prime}\right)$, and $2.82\left(1 \mathrm{H}\right.$, sept, $\left.\left.J=7.0 \mathrm{~Hz}, \mathrm{H}-15^{\prime}\right)\right)$, two para aromatic protons $\left(\delta_{\mathrm{H}} 6.98\left(1 \mathrm{H}, \mathrm{s}, \mathrm{H}-11^{\prime}\right)\right.$ and $\left.6.77\left(1 \mathrm{H}, \mathrm{s}, \mathrm{H}-14^{\prime}\right)\right)$, an ABX coupling system of one methine proton $\left(\delta_{\mathrm{H}} 2.07\left(1 \mathrm{H}, \mathrm{dd}, J=3.0,2.5 \mathrm{~Hz}, \mathrm{H}-5^{\prime}\right)\right)$, and two vinyl protons $\left(\delta_{\mathrm{H}} 5.87(1 \mathrm{H}, \mathrm{dd}, J=9.5\right.$, $\left.2.5 \mathrm{~Hz}, \mathrm{H}-6^{\prime}\right)$ and $\left.6.45\left(1 \mathrm{H}, \mathrm{dd}, J=9.5,3.0 \mathrm{~Hz}, \mathrm{H}-7^{\prime}\right)\right)$, together with a typical downshifted $\mathrm{H}_{\beta}-1$ signal 
of a dehydroabietane diterpene $\left(\delta_{\mathrm{H}} 2.22(1 \mathrm{H}, \mathrm{br} \mathrm{d}, J=13.0 \mathrm{~Hz})\right)$ [33]. The above NMR spectroscopic data suggested constituent lower monomer-2 was related to 6,7-dehydroferruginol [35]. Thus, the gross structure of 1 is composed of $7 \alpha$-hydrperoxyferruginol and 6,7-dehydroferruginol. The chemical shift of $\mathrm{H}-7$ appeared at the lower field region $\left(\delta_{\mathrm{H}} 5.86\right)$ in constituent monomer-1, comparing to that of the $7 \alpha$-hydroxyferruginol analogues [34] implied that the connectivity of two monomers between C-7 and C-12' through a peroxide functionality. The NOESY correlation between H-7 and H-11' $\left(\delta_{\mathrm{H}}\right.$ 6.98; Figure 3) further confirmed this proposal. Interestingly, there are some electrostatic attraction between the electron-rich aryl, the phenol functionality of upper $7 \alpha$-peroxyferruginol derivative, and the electron-deficient aryl, with peroxide moiety of lower 6,7-dehydroferruginol, formed the most stable conformer as shown in Figure 3. Due to the anisotropic effect from the opposite phenyl group, $\mathrm{H}-14, \mathrm{H}-15, \mathrm{H}-16, \mathrm{H}-17, \mathrm{H}-14^{\prime}, \mathrm{H}-15^{\prime}, \mathrm{H}-16^{\prime}, \mathrm{H}-17^{\prime}$, and phenol of 1 were posited in the shielding region and thus showed the higher field chemical shifts than that of the usual dehydroabietane diterpene. In contrast, $\mathrm{H}-5, \mathrm{H}-7$, and $\mathrm{H}-20^{\prime}$ of 1 were located in the deshielding region and thus exhibit a lower field chemical shifts than that of the usual dehydroabietane diterpene [33]. Complete ${ }^{1} \mathrm{H}$ - and ${ }^{13} \mathrm{C}-\mathrm{NMR}$ chemical shifts were established by ${ }^{1} \mathrm{H}-{ }^{1} \mathrm{H}$ COSY, HMQC, HMBC, and NOESY spectra. Based on these above evidences, compound 1 was elucidated as abieta-6,8,11,13-tetraen-12-yl 12-hydroxyabieta-8,11,13-trien-7 $\alpha$-yl peroxide.
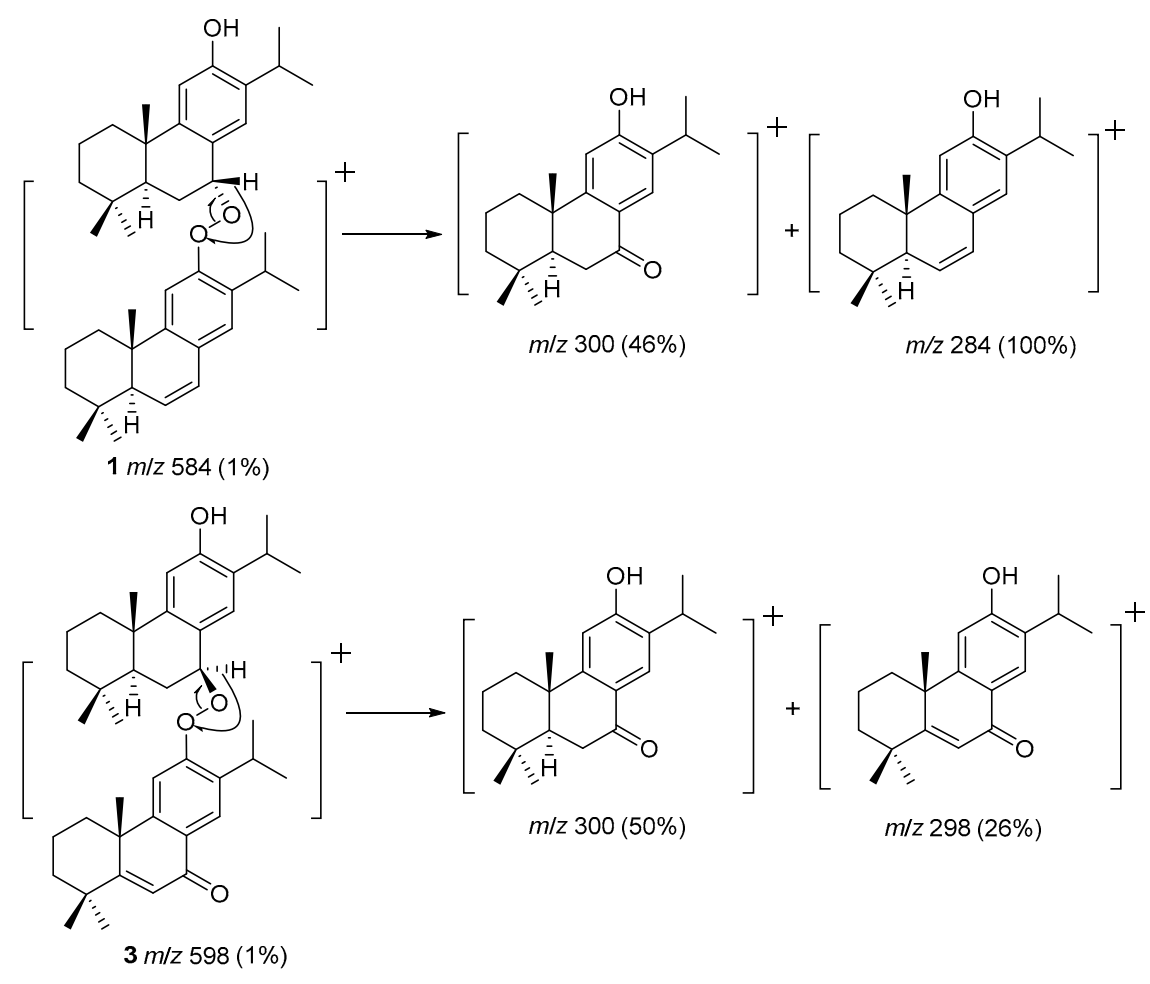

Figure 2. Some key electron impact (EI)-Mass fragmentations of compounds $\mathbf{1}$ and $\mathbf{3}$.

Compound 2 was an isomer of $\mathbf{1}$ with the same molecular formula $\mathrm{C}_{40} \mathrm{H}_{56} \mathrm{O}_{3}$, determined by the molecular ion of HR-EI-MS at $m / z$ 584.4237. Its EI-MS also showed the fragmental ions at $\mathrm{m} / \mathrm{z} 300$ $\left[\mathrm{C}_{20} \mathrm{H}_{28} \mathrm{O}_{2}\right]^{+}$and $284\left[\mathrm{C}_{20} \mathrm{H}_{28} \mathrm{O}\right]^{+}$, indicating that 2 was also a dimeric diterpenoid. The absorptions for hydroxyl $\left(3423 \mathrm{~cm}^{-1}\right)$ and aromatic $\left(3048,1590\right.$, and $1493 \mathrm{~cm}^{-1} ; \lambda_{\max } 217$ and $\left.276 \mathrm{~nm}\right)$ groups were also found in the UV and IR spectra. Comparison of ${ }^{1} \mathrm{H}$ and ${ }^{13} \mathrm{C}-\mathrm{NMR}$ data of 2 and $\mathbf{1}$ (Table 1) showed that the signals of constituent lower monomer- 2 of $\mathbf{2}$ were almost the same as those of $\mathbf{1}$, indicating the structure of constituent lower monomer-2 is related to 6,7-dehydroferruginol. The ${ }^{1} \mathrm{H}$ - and ${ }^{13} \mathrm{C}-\mathrm{NMR}$ data of $\mathbf{2}$ (Table 1) also showed another set of dehydroabietane diterpene signals for constituent upper monomer- 1 including three tertiary methyl groups $\left(\delta_{\mathrm{H}} 0.95,1.02\right.$, and 1.37 (each $3 \mathrm{H}, \mathrm{s}, \mathrm{Me}-18$, Me-19, and Me-20)), an isopropyl group attached to a phenyl group $\left(\delta_{\mathrm{H}} 1.16(3 \mathrm{H}, \mathrm{d}, J=7.0 \mathrm{~Hz}, \mathrm{Me}-17), 1.18\right.$ 
$(3 \mathrm{H}, \mathrm{d}, J=7.0 \mathrm{~Hz}, \mathrm{Me}-16)$, and $3.01(1 \mathrm{H}$, sept $, J=7.0 \mathrm{~Hz}, \mathrm{H}-15))$, two para aromatic protons $\left(\delta_{\mathrm{H}} 6.72(1 \mathrm{H}\right.$, $\mathrm{s}, \mathrm{H}-14)$ and $6.74(1 \mathrm{H}, \mathrm{s}, \mathrm{H}-11))$, a phenolic hydroxyl proton $\left(\delta_{\mathrm{H}} 4.52(1 \mathrm{H}, \mathrm{s})\right)$, and a typical downshifted $\mathrm{H}_{\beta}-1$ signal of a dehydroabietane diterpene $\left(\delta_{\mathrm{H}} 1.93(1 \mathrm{H}, \mathrm{br} d, J=12.0 \mathrm{~Hz})\right)$ [33]. A downshifted benzyl proton connected with a peroxyl group $\left(\delta_{\mathrm{H}} 5.20(1 \mathrm{H}, \mathrm{d}, J=8.0 \mathrm{~Hz}, \mathrm{H}-7)\right)$ was assigned as $\mathrm{H}-7$, suggesting by the ${ }^{1} \mathrm{H}-{ }^{1} \mathrm{H}$ COSY correlations with the two methylene protons of $\mathrm{H}-6\left(\delta_{\mathrm{H}} 2.24(1 \mathrm{H}, \mathrm{m}\right.$, $\left.\mathrm{H}_{\alpha}-6\right), \delta_{\mathrm{H}} 2.40\left(1 \mathrm{H}\right.$, br d, $\left.\left.J=8.0 \mathrm{~Hz}, \mathrm{H}_{\beta}-6\right)\right)$ and HMBC correlations with $\mathrm{C}-5\left(\delta_{\mathrm{C}} 47.6\right)$ and $\mathrm{C}-8\left(\delta_{\mathrm{C}}\right.$ 147.2; Figure 3). Since the ${ }^{1} \mathrm{H}-\mathrm{NMR}$ signal of $\mathrm{H}-7$ was a doublet peak with a constant coupling constant, 8.0 Hz, the peroxyl group on C-7 was in $\beta$-equational orientation (Figure 2), instead of in $\alpha$-axial orientation in 1 [33]. H-7 showed the NOESY correlation with $\mathrm{H}_{\alpha}-6\left(\delta_{\mathrm{H}} 2.24\right)$ and $1.59(\mathrm{H}-5, \mathrm{~m})$, but the lack of NOESY correlation with $\mathrm{H}_{\beta}-6\left(\delta_{\mathrm{H}} 2.40\right)$ further confirmed this proposal (Figure 3$)$. Thus, the structure of 2 was identified as abieta-6,8,11,13-tetraen-12-yl 12-hydroxyabieta-8,11,13-trien-7 $\beta$-yl peroxide. Compound 2 did not exhibit the most stable conformer as in $\mathbf{1}$. Therefore, the chemical shifts of two isopropyl groups in 2 were not shifted to the high field region.

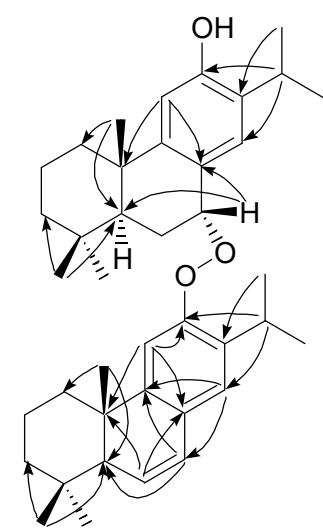

HMBC of 1

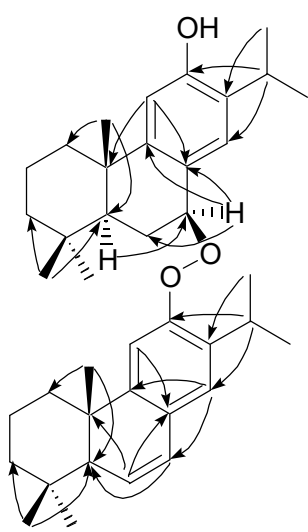

HMBC of 2

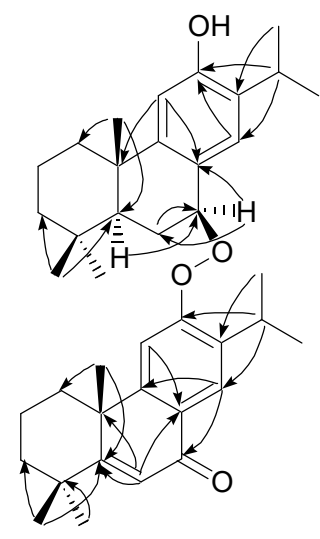

HMBC of 3

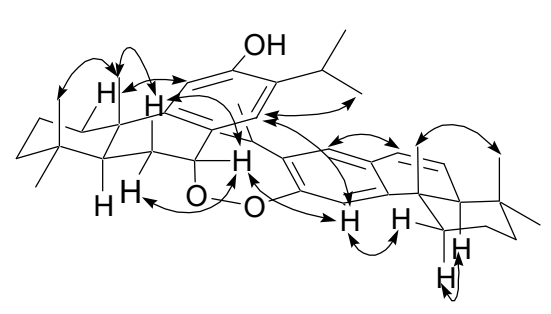

NOESY of 1

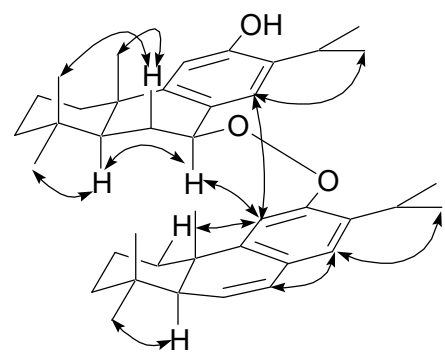

NOESY of 2

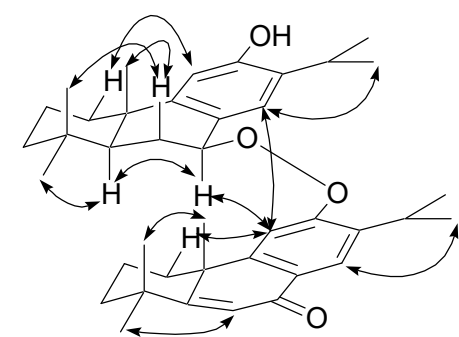

NOESY of 3

Figure 3. Significant HMBC (one-headed arrows) and NOESY (two-headed arrows) correlations of compounds 1-3.

The HR-EI-MS of 3 showed a molecular ion at $m / z$ 598.4018, which corresponded to the molecular formula, $\mathrm{C}_{40} \mathrm{H}_{54} \mathrm{O}_{4}$, indicating fourteen degrees of unsaturation. The EI-MS fragmental ions of 3 at $m / z 300\left[\mathrm{C}_{20} \mathrm{H}_{28} \mathrm{O}_{2}\right]^{+}$and $298\left[\mathrm{C}_{20} \mathrm{H}_{26} \mathrm{O}_{3}\right]^{+}$indicated that 3 was also a dimeric diterpenoid. The absorptions for hydroxyl $\left(3376 \mathrm{~cm}^{-1}\right)$, benzoyl $\left(1639 \mathrm{~cm}^{-1} ; \lambda_{\max } 233,282\right.$, and $\left.310 \mathrm{~nm}\right)$ and aromatic (3049, 1586, and $1467 \mathrm{~cm}^{-1}$ ) groups were also found in its UV and IR spectra. Comparison of ${ }^{1} \mathrm{H}$ - and ${ }^{13} \mathrm{C}-\mathrm{NMR}$ data of 3 and 2 (Table 1 ) showed that the signals of constituent monomer- 1 of 3 were almost the same as those of $\mathbf{2}$, indicating the structure of constituent upper monomer-1 is related to $7 \alpha$-peroxyferruginol. The ${ }^{1} \mathrm{H}$ - and ${ }^{13} \mathrm{C}$-NMR data of 3 (Table 1 ) also showed another set of dehydroabietane diterpene signals for constituent lower monomer-2 as follows: Three tertiary methyl groups $\left(\delta_{\mathrm{H}}\right.$ 0.97, 1.03, and 1.49 (each $3 \mathrm{H}, \mathrm{s}, \mathrm{Me}-18^{\prime}, \mathrm{Me}-19^{\prime}$, and Me-20)), an isopropyl group 
attached to a phenyl group $\left(\delta_{\mathrm{H}} 1.20\left(3 \mathrm{H}, \mathrm{d}, J=7.0 \mathrm{~Hz}, \mathrm{Me}-17^{\prime}\right), 1.23\left(3 \mathrm{H}, \mathrm{d}, J=7.0 \mathrm{~Hz}, \mathrm{Me}-16^{\prime}\right)\right.$ and $3.32\left(1 \mathrm{H}\right.$, sept, $\left.\left.J=7.0 \mathrm{~Hz}, \mathrm{H}-15^{\prime}\right)\right)$, two para aromatic protons $\left(\delta_{\mathrm{H}} 7.19\left(1 \mathrm{H}, \mathrm{s}, \mathrm{H}-11^{\prime}\right)\right.$ and $8.03(1 \mathrm{H}$, s, H-14')), one trisubstituted double bond $\left(\delta_{\mathrm{H}} 6.48\left(1 \mathrm{H}, \mathrm{s}, \mathrm{H}-6^{\prime}\right) ; \delta_{\mathrm{C}} 124.5\left(\mathrm{C}-6^{\prime}\right), 173.2\left(\mathrm{C}-5^{\prime}\right)\right)$, and a typical downshifted $\mathrm{H}_{\beta}-1$ signal of a dehydroabietane diterpene $\left(\delta_{\mathrm{H}} 2.51\left(1 \mathrm{H}, \mathrm{br} \mathrm{d}, J=13.5 \mathrm{~Hz}, \mathrm{H}-1^{\prime}\right)\right)$. The NMR spectroscopic data of constituent lower monomer-2 showed a close structural resemblance to that of 5,6-dehydrosugiol [36]. Thus, the structure of constituent lower monomer-2 was tentatively determined as 5,6-dehydrosugiol-related abietane. H-7 exhibited a doublet of a doublet signal with two coupling constants, 9.0 and $2.5 \mathrm{~Hz}$ and showed the NOESY correlation with $\mathrm{H}_{\alpha}-6\left(\delta_{\mathrm{H}} 2.24\right)$ and $\mathrm{H}-5\left(\delta_{\mathrm{H}} 1.72\right)$, but the lack of NOESY correlation with $\mathrm{H}_{\beta}-6\left(\delta_{\mathrm{H}} 2.41\right)$, which confirmed the peroxyl group was attached on C-7 in $\beta$-equational orientation (Figure 2) [33]. Thus, the structure of 3 was identified as 12-hydroxyabieta-8,11,13-trien-7 $\beta$-yl 7-oxoabieta-5,8,11,13-tetraen-12-yl peroxide.

Table 1. NMR (nuclear magnetic resonance) data $\left(\mathrm{CDCl}_{3}\right)$ of compound 1-3. $\delta$ in ppm, J in Hz.

\begin{tabular}{|c|c|c|c|c|c|c|}
\hline \multirow{2}{*}{ No. } & \multicolumn{2}{|r|}{1} & \multicolumn{2}{|r|}{2} & \multicolumn{2}{|r|}{3} \\
\hline & $\delta_{C}^{a}$ & $\delta_{\mathbf{H}} \mathbf{b}$ & $\delta_{C}$ & $\delta_{\mathbf{H}}$ & $\delta_{C}$ & $\delta_{\mathbf{H}}$ \\
\hline 1 & 41.4 & $1.78 \mathrm{~m}, 1.96$ br d (12.0) & 40.8 & $1.80 \mathrm{~m}, 1.93$ br d (12.0) & 41.0 & $1.78 \mathrm{~m}, 1.93$ br d (12.1) \\
\hline 2 & 18.8 & $1.59 \mathrm{~m}$ & 18.6 & $1.60 \mathrm{~m}$ & 18.6 & $1.59 \mathrm{~m}, 1.77 \mathrm{~m}$ \\
\hline 3 & 42.8 & $1.30 \mathrm{td}(13.0,3.5), 1.50 \mathrm{~m}$ & 42.6 & $1.25 \mathrm{~m}, 1.51 \mathrm{~m}$ & 42.4 & $1.25 \mathrm{~m}, 1.51 \mathrm{~m}$ \\
\hline 4 & 34.5 & & 34.8 & & 34.7 & \\
\hline 5 & 43.5 & $1.96 \mathrm{~m}$ & 47.6 & $1.59 \mathrm{~m}$ & 47.3 & $1.72 \mathrm{~m}$ \\
\hline 6 & 34.0 & $2.28 \mathrm{~m}, 2.32 \mathrm{~m}$ & 34.8 & 2.24 br d (14.0), $2.40 \mathrm{~m}$ & 34.2 & $2.24 \mathrm{br} \mathrm{d}(14.3), 2.41 \mathrm{~m}$ \\
\hline 7 & 97.0 & 5.86 br s & 104.1 & $5.20 \mathrm{~d}(8.0)$ & 102.7 & $5.38 \mathrm{dd}(9.0,2.5)$ \\
\hline 8 & 145.6 & & 147.2 & & 146.0 & \\
\hline 9 & 142.2 & & 143.1 & & 142.5 & \\
\hline 10 & 40.6 & & 40.7 & & 41.5 & \\
\hline 11 & 113.3 & $6.69 \mathrm{~s}$ & 113.5 & $6.74 \mathrm{~s}$ & 114.0 & $6.79 \mathrm{~s}$ \\
\hline 12 & 148.4 & & 148.9 & & 149.5 & \\
\hline 13 & 131.9 & & 132.8 & & 133.1 & \\
\hline 14 & 121.3 & $6.34 \mathrm{~s}$ & 120.9 & $6.72 \mathrm{~s}$ & 120.7 & $6.68 \mathrm{~s}$ \\
\hline 15 & 26.3 & 2.85 sept $(7.0)$ & 27.3 & 3.01 sept $(7.0)$ & 27.3 & 3.02 sept $(7.0)$ \\
\hline 16 & 22.3 & $0.78 \mathrm{~d}(7.0)$ & 22.6 & $1.18 \mathrm{~d}(7.0)$ & 22.5 & $1.16 \mathrm{~d}(7.0)$ \\
\hline 17 & 22.2 & $1.01 \mathrm{~d}(7.0)$ & 21.7 & $1.16 \mathrm{~d}(7.0)$ & 21.7 & $1.11 \mathrm{~d}(7.0)$ \\
\hline 18 & 33.5 & $0.97 \mathrm{~s}$ & 33.8 & $0.95 \mathrm{~s}$ & 33.7 & $0.97 \mathrm{~s}$ \\
\hline 19 & 23.2 & $0.98 \mathrm{~s}$ & 23.1 & $1.02 \mathrm{~s}$ & 23.1 & $1.01 \mathrm{~s}$ \\
\hline 20 & 21.9 & $1.36 \mathrm{~s}$ & 21.4 & $1.37 \mathrm{~s}$ & 21.7 & $1.36 \mathrm{~s}$ \\
\hline $12-\mathrm{OH}$ & & $4.33 \mathrm{~s}$ & & $4.52 \mathrm{~s}$ & & 4.52 \\
\hline $1^{\prime}$ & 36.2 & $1.55 \mathrm{~m}, 2.22$ br d (13.0) & 36.3 & $1.65 \mathrm{~m}, 2.13 \mathrm{~m}$ & 38.0 & $1.72 \mathrm{~m}, 2.51$ br d (13.5) \\
\hline $2^{\prime}$ & 19.0 & $1.75 \mathrm{~m}, 1.65 \mathrm{~m}$ & 18.8 & $1.69 \mathrm{~m}$ & 18.7 & $2.00 \mathrm{br} \mathrm{d}(13.5), 1.70 \mathrm{~m}$ \\
\hline $3^{\prime}$ & 41.0 & $1.23 \mathrm{~m}, 1.51 \mathrm{~m}$ & 40.9 & $1.23 \mathrm{~m}, 1.51 \mathrm{~m}$ & 40.3 & $1.45 \mathrm{~m}, 1.70 \mathrm{~m}$ \\
\hline $4^{\prime}$ & 32.8 & & 32.8 & & 37.5 & \\
\hline $5^{\prime}$ & 51.1 & $2.07 \mathrm{dd}(3.0,2.5)$ & 51.1 & $2.13 \mathrm{dd}(3.0,2.0)$ & 173.2 & \\
\hline $6^{\prime}$ & 127.6 & $5.87 \mathrm{dd}(9.5,2.5)$ & 128.0 & $5.90 \mathrm{dd}(9.5,3.0)$ & 124.5 & $6.48 \mathrm{~s}$ \\
\hline $7^{\prime}$ & 127.3 & $6.45 \mathrm{dd}(9.5,3.0)$ & 127.4 & $6.51 \mathrm{dd}(9.5,2.0)$ & 185.4 & \\
\hline $8^{\prime}$ & 126.5 & & 127.3 & & 124.5 & \\
\hline $9^{\prime}$ & 146.6 & & 146.9 & & 153.5 & \\
\hline $10^{\prime}$ & 38.1 & & 37.9 & & 41.4 & \\
\hline $11^{\prime}$ & 107.7 & $6.98 \mathrm{~s}$ & 109.1 & $6.95 \mathrm{~s}$ & 109.6 & $7.19 \mathrm{~s}$ \\
\hline $12^{\prime}$ & 152.9 & & 153.6 & & 158.2 & \\
\hline $13^{\prime}$ & 133.6 & & 135.4 & & 136.9 & \\
\hline $14^{\prime}$ & 124.4 & $6.77 \mathrm{~s}$ & 124.5 & $6.92 \mathrm{~s}$ & 124.5 & $8.03 \mathrm{~s}$ \\
\hline $15^{\prime}$ & 27.0 & 2.82 sept $(7.0)$ & 26.5 & 3.34 sept $(7.0)$ & 26.9 & 3.32 sept $(7.0)$ \\
\hline $16^{\prime}$ & 21.9 & $0.81 \mathrm{~d}(7.0)$ & 22.9 & $1.21 \mathrm{~d}(7.0)$ & 22.6 & $1.23 \mathrm{~d}(7.0)$ \\
\hline $17^{\prime}$ & 22.2 & $0.98 \mathrm{~d}(7.0)$ & 22.8 & $1.19 \mathrm{~d}(7.0)$ & 22.5 & $1.20 \mathrm{~d}(7.0)$ \\
\hline $18^{\prime}$ & 32.6 & $0.94 \mathrm{~s}$ & 32.6 & $0.97 \mathrm{~s}$ & 32.6 & $0.97 \mathrm{~s}$ \\
\hline $19^{\prime}$ & 22.5 & $1.04 \mathrm{~s}$ & 22.5 & $1.03 \mathrm{~s}$ & 29.0 & $1.03 \mathrm{~s}$ \\
\hline $20^{\prime}$ & 20.5 & $1.11 \mathrm{~s}$ & 23.0 & $1.00 \mathrm{~s}$ & 32.3 & $1.49 \mathrm{~s}$ \\
\hline
\end{tabular}

Recorded at ${ }^{\mathrm{a}} 100 \mathrm{MHz}\left({ }^{13} \mathrm{C}\right)$; and ${ }^{\mathrm{b}} 400 \mathrm{MHz}\left({ }^{1} \mathrm{H}\right)$. 
Four known compounds were identified by comparison of the NMR data with those described in the literatures as sugiol (4) [37], 16-hydroxysugiol (5) [38], 12-dehydroxy-15-hydroxysugiol (6) [39], and 12-O-acetylsugiol (7) [40].

\subsection{Inhibitory Activities Toward Xanthine Oxidase and Angiotensin-Converting Enzyme}

Xanthine oxidase is a key enzyme in purine metabolic pathway, catalyzing oxypurines (hypoxanthine and xanthine) to uric acid and plays an important role in causing gout [41]. Additionally, the angiotensin-converting enzyme (ACE) plays a key physiological role in blood pressure regulation of the renin-angiotensin system due to its action in the formation of angiotensin II, a potent vasoconstrictor, and in the degradation of bradykinin, a vasodilator [42]. Compounds 1-3 were evaluated using the above two enzyme inhibitory activities [43,44]. At the concentration of $50 \mu \mathrm{M}$, compounds 1-3 exhibited $26.2 \%, 23.6 \%$, and $35.7 \%$ xanthine oxidase inhibitory activity, respectively. Compound 3 also showed $24.9 \%$ ACE inhibitory activity, while compounds $\mathbf{1}$ and $\mathbf{2}$ were inactive. Analysis of the relationship between structure and activity in compounds 1-3 showed that the inhibitory activities toward the two above enzymes of compound 3 containing a 5,6-dehydrosugiol moiety at C-7 were higher than that of compounds 1 and $\mathbf{2}$ with a 6,7-dehydroferruginol moiety at C-7. Furthermore, the different orientations of the 7-substituent between compounds $\mathbf{1}$ and $\mathbf{2}$ had no significant effect on their xanthine oxidase inhibitory activity.

\section{Experimental Section}

\subsection{Chemicals}

Xanthine, Xanthine oxidase, and ACE (EC 3.4.15.1) from rabbit lungs, hippuryl-L-histidyl-L-leucine (HHL), ferulic acid (FA), sodium chloride $(\mathrm{NaCl})$, and sodium hydroxide $(\mathrm{NaOH})$ were purchased from Sigma Chemical Co. (St. Louis, MO, USA). Other chemicals used in this experiment were analytical grade. The water was obtained from a Milli-Q ${ }^{\circledR}$ (Millipore) water purification system (Billerica, MA, USA).

\subsection{General}

Optical rotations were made on a JASCO DIP-180 digital polarimeter. UV and IR spectra were recorded on a Shimadzu UV-1601PC and a Perkin-Elmer $983 \mathrm{G}$ spectrophotometer, respectively. ${ }^{1} \mathrm{H}$ and ${ }^{13} \mathrm{C}$-NMR spectra were acquired on a Varian-Unity-Plus-400 spectrometer with residual solvent signals as internal reference. Chemical shifts are given in $\delta$ values and coupling constants $(\mathrm{J})$ are given in hertz (Hz). EI-MS and HR-EI-MS were measured with a Jeol-JMS-HX300 mass spectrometer. Column chromatography (CC) was performed with silica gel (230-400 mesh; Merck \& Co., Inc., Kenilworth, NJ, USA). TLC was performed with pre-coated silica gel plates (60 F-254; Merck \& Co., Inc., Kenilworth, NJ, USA). Semi-preparative HPLC was performed using a normal phase column (Purospher STAR Si, $5 \mathrm{~mm}, 250 \times 10 \mathrm{~mm}$; Merck \& Co., Inc., Kenilworth, NJ, USA) on a LDC Analytical-III system.

\subsection{Plant Material}

The bark of $C$. japonica D. Don was collected in Sitou, Taiwan in June, 2000. The plant material was identified by Dr. Yen-Hsueh Tseng, Department of Forestry, National Chung-Hsing University (NCHU). A voucher specimen (TCF13443) was deposited at the Herbarium of the Department of Forestry, NCHU, Taiwan.

\subsection{Extraction and Isolation}

The air-dried bark of $C$. japonica $(16.0 \mathrm{~kg}$ ) was extracted by maceration with $\mathrm{MeOH}(100 \mathrm{~L})$ three times (seven days each time) at room temperature. After filtration, the combined $\mathrm{MeOH}$ extract was evaporated under reduced pressure to give a crude extract $(480 \mathrm{~g})$. The obtained extract was suspended in $\mathrm{H}_{2} \mathrm{O}(1 \mathrm{~L})$, and successively partitioned with EtOAc $(1 \mathrm{~L})$ and $n$ - $\mathrm{BuOH}(1 \mathrm{~L})$ three times. The EtOAc 
soluble fraction $(430 \mathrm{~g})$ was loaded onto a silica gel $(4.0 \mathrm{~kg})$ column and eluted with $n$-hexane-EtOAc and EtOAc-MeOH mixtures to give 11 fractions, fr. 1 (2.6 g), 2 (29.4 g), 3 (47.8 g), 4 (92.4 g), 5 (21.6 g), 6 (18.1 g), 7 (22.5 g), 8 (35.8 g), 9 (19.2 g), 10 (44.2 g), and 11 (72.2 g). Fr. 3 from hexane/EtOAc (9:1) elution was further purified through a silica gel column $(7 \mathrm{~cm} \times 60 \mathrm{~cm})$ and eluted with hexane $/ \mathrm{CH}_{2} \mathrm{Cl}_{2}$ $(1: 0-0: 1 v / v)$ to obtain nine fractions, 3A-3I. Further purification of subfraction 3E by HPLC gave 4 $(15.1 \mathrm{mg})$ and $7(1.5 \mathrm{mg})$ using hexane/EtOAc $(9: 1 \mathrm{v} / \mathrm{v})$. Further purification of subfraction 3G by HPLC gave $3(2.4 \mathrm{mg})$ using hexane/EtOAc (10:1 v/v). Further purification of subfraction $3 \mathrm{H}$ by HPLC gave 1 $(1.6 \mathrm{mg})$ and $2(3.3 \mathrm{mg})$ using hexane/EtOAc $(9: 1 \mathrm{v} / v)$. Fr. 5 from $n$-hexane-EtOAc $(7: 3 \mathrm{v} / v)$ elution was further purified over a silica gel column $(5 \mathrm{~cm} \times 45 \mathrm{~cm})$, eluted with $n$-hexane- $\mathrm{CH}_{2} \mathrm{Cl}_{2}-\mathrm{EtOAc}$ (8:8:1 to $0: 1: 1 v / v / v)$ to yield fifteen fractions, $5 \mathrm{~A}-5 \mathrm{O}$. Further purification of subfraction $5 \mathrm{E}$ by HPLC gave 5 $(0.5 \mathrm{mg})$ and $6(1.9 \mathrm{mg})$ using $n$-hexane-EtOAc $(7: 3 \mathrm{v} / \mathrm{v})$.

Abieta-6,8,11,13-tetraen-12-yl 12-hydroxyabieta-8,11,13-trien-7 $\alpha$-yl peroxide (1). Gum; $[\alpha]_{\mathrm{D}}^{25}:-21.2$ ( $c=0.7, \mathrm{CHCl}_{3}$ ); EI-MS (70 eV) m/z (rel. int.): 584 ([M] $\left.{ }^{+}, 1\right), 300$ (77), 284 (100), 269 (18), 227 (15), 213 (39), 202 (530), 189 (91); HR-EI-MS m/z: 584.4238 [M] ${ }^{+}$(calculated for $\mathrm{C}_{40} \mathrm{H}_{56} \mathrm{O}_{3}$ 584.4232); UV (MeOH) $\lambda_{\max }(\log \varepsilon): 220$ (4.74), 279 (4.41) nm; IR (KBr) $v_{\max }: 3409$, 3049, 1593, 1487, 1460, 1407, 1255, 1169, $1043,1009,890 \mathrm{~cm}^{-1}$; ${ }^{1} \mathrm{H}-\mathrm{NMR}$ and ${ }^{13} \mathrm{C}-\mathrm{NMR}\left(400 / 100 \mathrm{MHz}\right.$, in $\left.\mathrm{CDCl}_{3}\right)$ : See Table 1 ; chemical spectra is in the Supplementary Materials.

Abieta-6,8,11,13-tetraen-12-yl 12-hydroxyabieta-8,11,13-trien-7 $\beta$-yl peroxide (2). Gum; $[\alpha]_{\mathrm{D}}^{25}:-54.6$ $\left(c=1.0, \mathrm{CHCl}_{3}\right)$; EI-MS (70 eV) m/z (rel. int.): 584 ([M] $\left.{ }^{+}, 1\right), 582$ (3), 473 (7), 313 (5), 300 (45), 284 (100), 269 (9), 213 (15), 202 (30), 189 (25), 59 (14); HR-EI-MS: $m / z: 584.4237$ [M] ${ }^{+}$(calculated for $\mathrm{C}_{40} \mathrm{H}_{56} \mathrm{O}_{3}$ 584.4232); UV (MeOH) $\lambda_{\max }(\log \varepsilon): 217$ (4.80), 276 (4.45) nm; IR (KBr) $v_{\max } 3423,3048,1590,1493,1460$, 1407, 1261, 1169, 1062, 1036, 1003, 963, 890, $738 \mathrm{~cm}^{-1}$; ${ }^{1} \mathrm{H}-\mathrm{NMR}$ and ${ }^{13} \mathrm{C}-\mathrm{NMR}\left(400 / 100 \mathrm{MHz}\right.$, in $\left.\mathrm{CDCl}_{3}\right)$ : See Table 1; chemical spectra is in the Supplementary Materials.

12-Hydroxyabieta-8,11,13-trien-7 $\beta$-yl 7-oxoabieta-5,8,11,13-tetraen-12-yl peroxide (3). Gum; $[\alpha]_{D}^{25}$ : $-39.7\left(c=0.8, \mathrm{CHCl}_{3}\right)$; EI-MS m/z $598\left([\mathrm{M}]^{+}, 1\right), 300$ (50), 298 (26), 285 (63), 229 (47), 213 (41), 203 (37), 189 (100), 69 (37), 55 (44); HR-EI-MS $m / z$ [M] ${ }^{+}: 598.4018$ [M] ${ }^{+}$(calculated for $\mathrm{C}_{40} \mathrm{H}_{54} \mathrm{O}_{4}$ 598.4024); UV $(\mathrm{MeOH}) \lambda_{\max }(\log \varepsilon): 233$ (4.34), $282(4.08), 310(3.88) \mathrm{nm}$; IR (KBr) $v_{\max } 3376,3049,1639,1586,1467$, 1407, 1275, 1182, 1036, 990, $897 \mathrm{~cm}^{-1} ;{ }^{1} \mathrm{H}-\mathrm{NMR}$ and ${ }^{13} \mathrm{C}-\mathrm{NMR}$ (400/100 MHz, in $\left.\mathrm{CDCl}_{3}\right)$ : See Table 1; chemical spectra is in the Supplementary Materials.

\subsection{Xanthine Oxidase Inhibition Assay}

The inhibitory effect on xanthine oxidase of compounds 1-3 was measured spectrophotometrically according to the method reported by Chen et al. with minor modifications [43]. The mixture assay consisted of a $35 \mu \mathrm{L}$ of $0.1 \mathrm{mM}$ phosphate buffer $(\mathrm{pH}=7.5), 30 \mu \mathrm{L}$ of enzyme solution $(0.01 \mathrm{units} / \mathrm{mL}$ in $0.1 \mathrm{mM}$ phosphate buffer, $\mathrm{pH}=7.5$ ), and $20 \mu \mathrm{L}$ of the sample solution (final concentration was $50 \mu \mathrm{M}$ ). The mixture was pre-incubated at $25^{\circ} \mathrm{C}$ for $15 \mathrm{~min}$, and then was initiated by adding $60 \mu \mathrm{L}$ of substrate solution ( $150 \mathrm{mM}$ xanthine in the same buffer). The reaction mixture was incubated for further $30 \mathrm{~min}$ at $25^{\circ} \mathrm{C}$. The reaction was stopped by adding $50 \mu \mathrm{L}$ of $2 \mathrm{~N} \mathrm{HCl}$, and the absorbance was measured at $290 \mathrm{~nm}$ using a microplate reader. The percentage activity of xanthine oxidase was calculated as following the formula: XO Inhibition $(\%)=(1-\mathrm{B} / \mathrm{A}) \times 100$, where $\mathrm{A}$ and $\mathrm{B}$ are the activities of the enzyme without and with test sample. Quercetin, a known inhibitor of xanthine oxidase, was used as a positive control, whereas a negative control was performed without any inhibitor.

\subsection{Angiotensin-I Converting Enzyme (ACE) Inhibition Assay}

ACE assay was performed using the modified spectrophotometric method described by Cushman and Cheung with minor modifications [44]. The assay mixture contained $30 \mu \mathrm{L} 2.5 \mathrm{mM}$ Hippuryl-Lhistidyl-L-leucine (HHL), $10 \mu \mathrm{L}$ of testing sample at a certain concentration, and $20 \mu \mathrm{L}$ of ACE $(0.05 \mathrm{mU} / \mu \mathrm{L})$ in $200 \mathrm{mM}$ borate buffer containing $300 \mathrm{mM} \mathrm{NaCl}$ (adjusted to $\mathrm{pH}$ 8.3). The mixture was incubated at $37^{\circ} \mathrm{C}$ for $60 \mathrm{~min}$, and then was halted by addition of $30 \mu \mathrm{L}$ of $2 \mathrm{~N} \mathrm{HCl}$. The substrate 
HHL and product hippuric acid (HA) liberated through hydrolysis of HHL were determined by HPLC equipped with a Hypersil GOLD C-18 analytical column $(250 \mathrm{~mm} \times 4.6 \mathrm{~mm}, 5 \mu \mathrm{m})$. The column was eluted with a mobile phase of $23 \%$ ACN containing $0.1 \%$ TFA at a constant flow rate of $1 \mathrm{~mL} / \mathrm{min}$ for $15 \mathrm{~min}$ and monitored for absorbance at $228 \mathrm{~nm}$. The inhibition activity was calculated using the following formula: ACE Inhibition $(\%)=\left[1-\left(\Delta \mathrm{A}_{\text {Inhibitor }} / \Delta \mathrm{A}_{\text {Blank }}\right)\right] \times 100$, where $\Delta \mathrm{A}_{\text {Inhibitor }}$ and $\Delta \mathrm{A}_{\text {Blank }}$ were the peak areas of HA in testing and blank samples, respectively. Captopril, a known inhibitor of $\mathrm{ACE}$, was used as a positive control, whereas a negative control was performed without any inhibitor.

\section{Conclusions}

In this study, three new dimeric abietanoid peroxides, abieta-6,8,11,13-tetraen-12-yl 12hydroxyabieta-8,11,13-trien-7 $\alpha$-yl peroxide (1), abieta-6,8,11,13-tetraen-12-yl 12-hydroxyabieta-8,11,13trien-7 $\beta$-yl peroxide (2), and 12-hydroxyabieta-8,11,13-trien-7 $\beta$-yl 7-oxoabieta-5,8,11,13- tetraen-12-yl peroxide (3), together with four known abietane-type diterpenoids (4-7) were isolated and characterized from the bark of $C$. japonica. At a concentration of $50 \mu \mathrm{M}$, the three new compounds exhibited the xanthine oxidase inhibitory activity. In addition, compounds 3 also showed ACE inhibitory activity.

Supplementary Materials: The following are available online. ${ }^{1} \mathrm{H}-\mathrm{NMR},{ }^{13} \mathrm{C}-\mathrm{NMR}, \mathrm{HMQC}, \mathrm{HMBC},{ }^{1} \mathrm{H}-{ }^{1} \mathrm{H}$ COSY, NOESY, EIMS, infrared, and ultraviolet-visible spectra of compounds $1-3 .{ }^{1} \mathrm{H}-\mathrm{NMR}$ spectra of compounds 4-7.

Author Contributions: The study was designed by Y.-H.K. and was performed the experiments, analyzed the data, and wrote the manuscript by C.-I.C., C.-C.C. and C.-R.C. C.-I.C., C.-C.C. and M.-D.W. analyzed the data, and contributed to discussions. Y.-H.K., M.-J.C. and P.-J.S. contributed to discussions and reviewed the manuscripts. All authors read and approved the final version of the manuscript.

Funding: This work was financially supported by the "Chinese Medicine Research Center, China Medical University" from The Featured Areas Research Center Program within the framework of the Higher Education Sprout Project by the Ministry of Education (MOE) in Taiwan (CMRC-CHM-4) and Taiwan Ministry of Health and Welfare Clinical Trial Center (MOHW108-TDU-B-212-133004).

Acknowledgments: We thank Shu-Yun Sun and Lih-Mei Sheu for the EI-MS and HR-EI-MS measurement in the Instrumentation Center of the College of Science, National Taiwan University and National Chung Hsing University. We are also grateful to the National Center for High-performance Computing for computer time and facilities.

Conflicts of Interest: The authors declare no conflict of interest.

\section{References}

1. Gan, W.S. Manual of Medicine Plants in Taiwan; National Research Institute of Chinese Medicine: Taipei, Taiwan, 1958; Volume 1, p. 54.

2. Shieh, M.; Iizuka, Y.; Matsubara, Y. Monoterpenoid and sesquiterpenoid constituents of the essential oil of sugi (Cryptomeria japonica D. Don.). Agric. Biol. Chem. 1981, 45, 1493-1495. [CrossRef]

3. Nagahama, S.; Tazaki, M. Terpenoids of wood oil of sugi (Cryptomeria japonica). Peculiarities of Obisugi variety. Mokuzai Gakkaishi 1993, 39, 1077-1083.

4. Nagahama, S.; Tazaki, M.; Sanetika, T.; Nishimura, K.; Tajima, M. Terpenoids of the wood oil of sugi (Cryptomeria japonica). III. Components of Yakusugi. Mokuzai Gakkaishi 1996, 42, 1121-1126.

5. Nagahama, S.; Tazaki, M.; Nomura, H.; Nishimura, K.; Tajima, M.; Iwasita, Y. Terpenoids of the wood oil of sugi (Cryptomeria japonica) IV. Components of form Yabukuguri. Mokuzai Gakkaishi 1996, 42, 1127-1133.

6. Nagahama, S.; Tazaki, M.; Sanetika, T.; Nishimura, K.; Tajima, M. Terpenoids of the wood oil of sugi (Cryptomeria japonica) V. Components of from Ayasugi. Mokuzai Gakkaishi 1998, 44, 282-286.

7. Morita, S.; Yatagai, M.; Fujita, S. Distributions of the extracts and sesquiterpenes in the trunk of Yakusugi (Cryptomeria japonica). Mokuzai Gakkaishi 1995, 41, 938-944.

8. Narita, H.; Yatagai, M.; Ohira, T. Chemical composition of the essential oils from bogwood of Cryptomeria japonica D. Don. J. Essent. Oil Res. 2006, 18, 68-70. [CrossRef] 
9. Shimizu, M.; Tsuji, H.; Shogawa, H.; Fukumura, H.; Tanaami, S.; Hayashi, T.; Arisawa, M.; Morita, N. Anti-inflammatory constituents of topically applied crude drugs. II. Constituents and anti-inflammatory effect of Cryptomeria japonica D. Don. Chem. Pharm. Bull. 1988, 36, 3967-3973. [CrossRef] [PubMed]

10. Nagahama, S.; Tazaki, M.; Kobayashi, H.; Sumimoto, M. Sesquiterpene alcohols from Cryptomeria japonica and C. Fortunei leaf oil. Phytochemistry 1993, 33, 879-882. [CrossRef]

11. Su, W.C.; Fang, J.M.; Cheng, Y.S. Hexacarbocyclic triterpenes from leaves of Cryptomeria japonica. Phytochemistry 1993, 34, 779-782. [CrossRef]

12. Su, W.C.; Fang, J.M.; Cheng, Y.S. Abietanes and kauranes from leaves of Cryptomeria japonica. Phytochemistry 1994, 35, 1279-1284. [CrossRef]

13. Su, W.C.; Fang, J.M.; Cheng, Y.S. Labdanes from leaves of Cryptomeria japonica. Phytochemistry 1994, 37, 1109-1114.

14. Su, W.C.; Fang, J.M.; Cheng, Y.S. Sesquiterpenes from leaves of Cryptomeria japonica. Phytochemistry 1995, 39, 603-607.

15. Su, W.C.; Fang, J.M.; Cheng, Y.S. Diterpenoids from leaves of Cryptomeria japonica. Phytochemistry 1996, 41, 255-261.

16. Su, W.C.; Fang, J.M.; Cheng, Y.S. Synthesis and structure determination of cryptomanhydride, an uncommon natural terpenic anhydride. Tetrahedron Lett. 1995, 36, 5367-5370. [CrossRef]

17. Chen, X.H.; Kim, C.S.; Kashiwagi, T.; Tebayashi, S.I.; Horiike, M. Antifeedants against Acusta despesta from the Japanese cedar, Cryptomeria japonica II. Biosci. Biotechnol. Biochem. 2001, 65, 1434-1437. [CrossRef] [PubMed]

18. Morisawa, J.; Kim, C.S.; Kashiwagi, T.; Tebayashi, S.I.; Horiike, M. Repellents in the Japanese cedar, Cryptomeria japonica, against the pill-bug, Armadillidium vulgare. Biosci. Biotechnol. Biochem. 2002, 66, 2424-2428. [CrossRef] [PubMed]

19. Arihara, S.; Umeyama, A.; Bando, S.; Imoto, S.; Ono, M.; Tani, M.; Yoshikawa, K. A new abietane and two dimeric abietane diterpenes from the black heartwood of Cryptomeria japonica. Chem. Pharm. Bull. 2004, 52, 354-358. [CrossRef]

20. Shibuya, T. Cryptoquinonemethides D and E, C 30-terpene quinone methides, from Cryptomeria japonica. Phytochemistry 1992, 31, 4289-4294. [CrossRef]

21. Yoshikawa, K.; Tanaka, T.; Umeyama, A.; Arihara, S. Three abietane diterpenes and two diterpenes incorporated sesquiterpenes from the bark of Cryptomeria japonica. Chem. Pharm. Bull. 2006, 54, 315-319. [CrossRef]

22. Yoshikawa, K.; Suzuki, K.; Umeyama, A.; Arihara, S. Abietane diterpenoids from the barks of Cryptomeria japonica. Chem. Pharm. Bull. 2006, 54, 574-578. [CrossRef] [PubMed]

23. Kofujita, H.; Ota, M.; Takahashi, K.; Kawai, Y.; Hayashi, Y. A diterpene quinone from the bark of Cryptomeria japonica. Phytochemistry 2002, 61, 895-898. [CrossRef]

24. Moiteiro, C.; Esteves, T.; Ramalho, L.; Rojas, R.; Alvarez, S.; Zacchino, S.; Bragança, H. Essential oil characterization of two Azorean Cryptomeria japonica populations and their biological evaluations. Nat. Prod. Commun. 2013, 8, 1785-1790. [CrossRef] [PubMed]

25. Horiba, H.; Nakagawa, T.; Zhu, Q.; Ashour, A.; Watanabe, A.; Shimizu, K. Biological activities of extracts from different parts of Cryptomeria japonica. Nat. Prod. Commun. 2016, 11, 1337-1342. [CrossRef] [PubMed]

26. Shyur, L.F.; Huang, C.C.; Lo, C.P.; Chiu, C.Y.; Chen, Y.P.; Wang, S.Y.; Chang, S.T. Hepatoprotective phytocompounds from Cryptomeria japonica are potent modulators of inflammatory mediators. Phytochemistry 2008, 69, 1348-1358. [CrossRef] [PubMed]

27. Wu, B.; Kashiwagi, T.; Kuroda, I.; Chen, X.H.; Tebayashi, S.I.; Kim, C.S. Antifeedants against Locusta migratoria from the Japanese Cedar, Cryptomeria japonica II. Biosci. Biotechnol. Biochem. 2008, 72, 611-614. [CrossRef] [PubMed]

28. Chen, C.C.; Wu, J.H.; Yang, N.S.; Chang, J.Y.; Kuo, C.C.; Wang, S.Y.; Kuo, Y.H. Cytotoxic C $_{35}$ terpenoid cryptotrione from the bark of Cryptomeria japonica. Org. Lett. 2010, 12, 2786-2789. [CrossRef] [PubMed]

29. Chang, C.I.; Wang, S.S.; Wu, M.D.; Cheng, M.J.; Ko, H.H.; Chang, H.S.; Chen, J.J.; Chen, C.C.; Kuo, Y.H. Two new sesquarterpenoids from the bark of Cryptomeria japonica. Phytochem. Lett. 2017, 22, 56-60. [CrossRef]

30. Chang, C.I.; Chen, C.C.; Wang, S.Y.; Chao, C.Y.; Chao, L.K.; Chen, J.J.; Ko, H.H.; Chen, C.C.; Kuo, Y.H. Three new abietane-type diterpenes from the bark of Cryptomeria japonica. Helv. Chim. Acta 2016, 99, 710-715. [CrossRef] 
31. Chang, C.I.; Chen, C.C.; Wang, S.Y.; Chang, H.S.; Chao, L.K.; Chen, J.J.; Chen, C.C.; Kuo, Y.H. Three new abietane-type diterpenes from the bark of Cryptomeria japonica. Phytochem. Lett. 2017, 19, 46-49. [CrossRef]

32. Chang, C.I.; Chen, C.C.; Chao, C.Y.; Ko, H.H.; Chang, H.S.; Wang, S.Y.; Chen, J.J.; Chen, C.C.; Kuo, Y.H. Two new abietane-type diterpenes from the bark of Cryptomeria japonica. Nat. Prod. Commun. 2017, 12, 1553-1555. [CrossRef]

33. Kuo, Y.H.; Chen, C.H.; Wein, Y.S. New dimeric monoterpenes and dimeric diterpenes from the heartwood of Chamaecyparis obtusa var. formosana. Helv. Chim. Acta 2002, 85, 2657-2663. [CrossRef]

34. Dellar, J.E.; Cole, M.D.; Waterman, P.G. Antimicrobial abietane diterpenoids from Plectranthus elegans. Phytochemistry 1996, 41, 735-738. [CrossRef]

35. Ernst, H.; Guenter, M. Synthese von (+)-Taxodion. Justus Liebigs Ann. Chem. 1989, 7, 677-686.

36. Yang, J.; Peng, C.Z.; Jiang, J.; Huang, G.; Liu, Y. Chemical Constituents of Podocarpus wallichiana. Chem. Nat. Compd. 2016, 52, 142-143. [CrossRef]

37. Zhao, H.; Li, H.; Huang, G.; Chen, Y. A new abietane mono-norditerpenoid from Podocarpus nagi. Nat. Prod. Res. 2017, 31, 844-848. [CrossRef]

38. Miron-Lopez, G.; Bazzocchi, I.L.; Jimenez-Diaz, I.A.; Moujir, L.M.; Quijano-Quinones, R.; Quijano, L.; Mena-Rejon, G.J. Cytotoxic diterpenes from roots of Crossopetalum gaumeri, a Celastraceae species from Yucatan Peninsula. Bioorganic. Med. Chem. Lett. 2014, 24, 2105-2109. [CrossRef] [PubMed]

39. Pereda-Miranda, R.; Delgado, G.; Vivar, A.R.D. An abietane diterpenoid from Salvia sapinae. Phytochemistry 1986, 25, 1931-1933. [CrossRef]

40. Kuo, Y.H.; Wu, T.R.; Cheng, M.C.; Wang, Y. Five new compounds from the heartwood of Juniperus formosana HAYATA. Chem. Pharm. Bull. 1990, 38, 3195-3201. [CrossRef]

41. Cos, P.; Ying, L.; Calomme, M.; Hu, J.P.; Cimanga, K.; Van, P.B.; Pieters, L.; Vlietinck, A.J.; Vanden, B.D. Structure-activity relationship and classification of flavonoids as inhibitors of xanthine oxidase and superoxide scavengers. J. Nat. Prod. 1998, 61, 71-76. [CrossRef]

42. Soffer, R.L. Angiotensin-converting enzyme and the regulation of vasoactive peptides. Annu. Rev. Biochem. 1976, 45, 73-94. [CrossRef] [PubMed]

43. Chen, C.H.; Chan, H.C.; Chu, Y.T.; Ho, H.Y.; Chen, P.Y.; Lee, T.H.; Lee, C.K. Antioxidant activity of some plant extracts towards xanthine oxidase, lipoxygenase and tyrosinase. Molecules 2009, 14, 2947-2958. [CrossRef] [PubMed]

44. Cushman, D.W.; Cheung, H.S. Spectrophotometric assay and properties of the angiotensin-converting enzyme of rabbit lung. Biochem. Pharm. 1971, 20, 1637-1648. [CrossRef]

Sample Availability: Samples of the compounds are not available from the authors.

(C) 2019 by the authors. Licensee MDPI, Basel, Switzerland. This article is an open access article distributed under the terms and conditions of the Creative Commons Attribution (CC BY) license (http://creativecommons.org/licenses/by/4.0/). 